\title{
Obituary
}

\section{Professor T. C. Highton, University of Otago (1917-1976)}

Professor Thomas Cecil Highton died suddenly on April 26, 1976. With his death New Zealand has lost a prominent member of the medical profession and a rheumatologist of international standing.

Born in South Africa on October 3, 1917, he went to England with his parents during his early childhood. He graduated M.B., Ch.B. from the University of Liverpool in 1942. As a student he gained distinction in pharmacology and therapeutics, the medal in forensic medicine, and the Owen $T$. Williams Prize for the highest aggregate mark in medicine, surgery, and obstetrics. During the second world war he saw active service with the Royal Navy as a surgeon-lieutenant, and while still on active service obtained membership of the Royal College of Physicians of London.

His career in rheumatology began after his discharge from the Navy, when he was appointed as Senior Medical Registrar at the West London Hospital. Here he trained under the late Dr. W. S. C. Copeman, and he later worked with Dr. (later Professor) E. G. L. Bywaters at Hammersmith Hospital. During this period he held a Nuffield Fellowship and later was the Saltwell Scholar of the Royal College of Physicians.

In 1951 he was appointed as Research Medical Officer at the Queen Elizabeth Hospital, Rotorua, New Zealand, and in 1957 took up a Medical
Research Council post in the Department of Medicine, University of Otago Medical School. Here he pioneered research into the rheumatic diseases and built up a clinical rheumatological service. His principal research interests lay in electron microscope studies of synovial tissue and cartilage, and in the nature and role of mucopolysaccharides and collagen in connective tissue; he was always interested in the likelihood of an infective agent being an aetiological factor in rheumatoid disease. $\mathrm{He}$ was a meticulous physician who gave a devoted service to his patients, and he had a high reputation as a teacher.

Professor Highton was a past-President of the New Z.ealand Rheumatism Association, a Councillor of the International League Against Rheumatism, Vice-President of the South East Asian and Pacific Area League Against Rheumatism, and an honorary member of the American and Indian Rheumatism Associations. He was Chairman of the ILAR Standing Committee for International Clinical Studies. He was appointed Associate Professor in Medicine in 1968 and was awarded a personal chair in Medicine at the University of Otago in 1975.

Our deepest sympathies go to his wife, Dr. Roberta Highton, and to his four children.

D. G. Palmer 